UNIVERSITY OF OKLAHOMA

GRADUATE COLLEGE

HOW OUTSTANDING LEADERS LEAD WITH AFFECT: AN EXAMINATION

OF CHARISMATIC, IDEOLOGICAL, AND PRAGMATIC LEADERS

\author{
A DISSERTATION \\ SUBMITTED TO THE GRADUATE FACULTY \\ in partial fulfillment of the requirements for the \\ Degree of \\ DOCTOR OF PHILOSOPHY
}

By

JENNIFER GRIFFITH

Norman, Oklahoma

2013 


\section{HOW OUTSTANDING LEADERS LEAD WITH AFFECT: AN EXAMINATION OF CHARISMATIC, IDEOLOGICAL, AND PRAGMATIC LEADERS}

\section{A DISSERTATION APPROVED FOR THE DEPARTMENT OF PSYCHOLOGY}

BY

Dr. Shane Connelly, Chair

Dr. Michael Mumford

Dr. Lori Anderson Snyder

Dr. Robert Terry

Dr. Matthew Jensen 
(C) Copyright by JENNIFER GRIFFITH 2013

All Rights Reserved. 


\section{Acknowledgements}

There are many people who contributed to the present effort that I would like to thank. First, I would like to extend thanks to Dr. Shane Connelly, my advisor, for her guidance and honest feedback on this project in addition to the many endeavors I have undertaken in graduate school. I would also like to thank the members of my committee, Dr. Michael Mumford, Dr. Lori Anderson Snyder, Dr. Robert Terry, and Dr. Matthew Jensen for their honest and constructive feedback during this process. I would also like to thank several of my colleagues, especially Thomas Zeni, Chase Thiel, and Genevieve Johnson for their invaluable input on research design and variable selection. Additionally, I would like to thank the subject matter experts, Jamie Barrett, William Vessey, Michael Hughes, Carter Gibson, and Jensen Mecca, whose hard work classifying outstanding leaders prior to this project helped to get me started on the right track. Similarly, I must thank the entire undergraduate and graduate team of coders on this project for their patience and continued motivation to complete this project. I especially thank Jonathan Bateman for his role as an outstanding undergraduate research assistant. Finally, I would like to thank my parents and Christopher Scott for their love, support, and encouragement. I love you more than I can express. 


\section{Table of Contents}

Acknowledgement....................................................iv

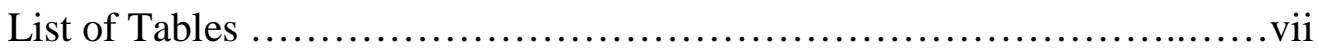

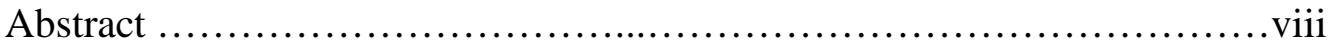

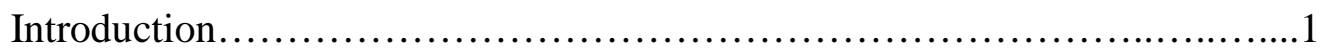

The CIP Model of Leadership .......................................3

Charismatic Leadership....................................4

Ideological Leadership .....................................4

Pragmatic Leadership.......................................5

Emotional Displays and CIP Leader Type ............................5

Emotional Displays and Influence Tactics ...........................8

Leadership Outcomes.........................................9

Communication Effectiveness..............................10

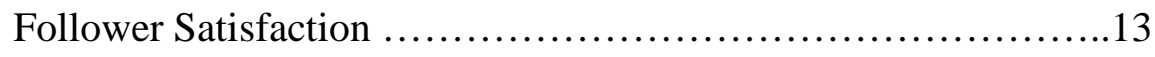

Leadership Effectiveness................................15

Method.................................................................... 17

Sample.......................................................17

Data Sources.......................................................21

Biography Selection......................................21

Speech Excerpt Selection ..................................23

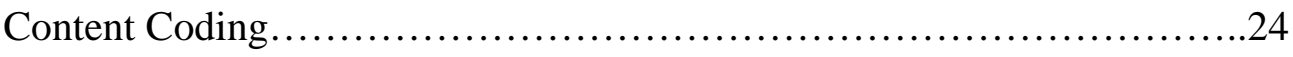

Predictors..............................................25 


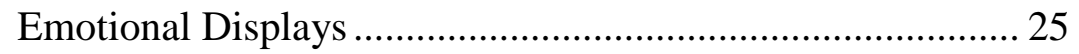

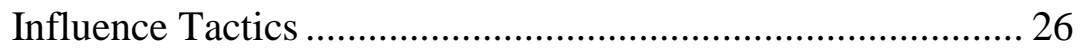

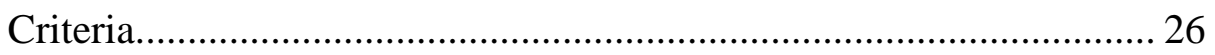

Communication Effectiveness ............................................. 26

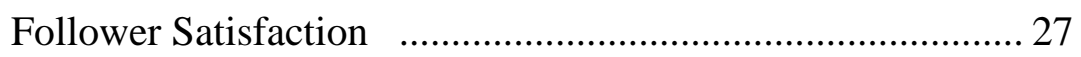

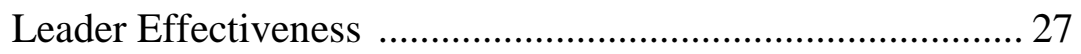

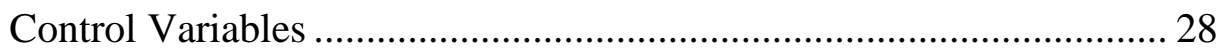

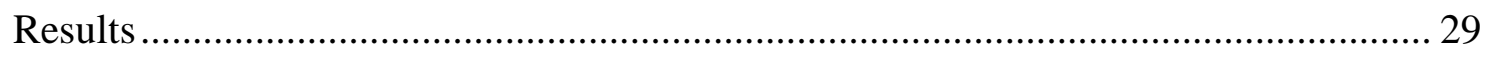

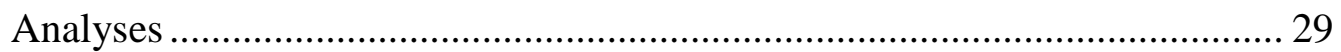

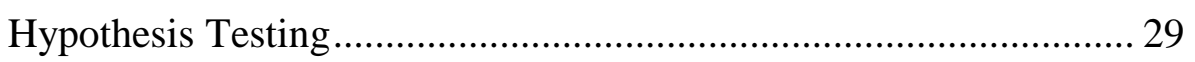

CIP Leader Type Mean Differences ................................ 29

CIP Leader Type Emotional Styles ................................... 31

Affective Congruence ………………………………..... 32

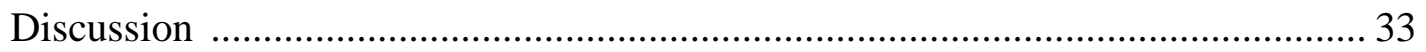

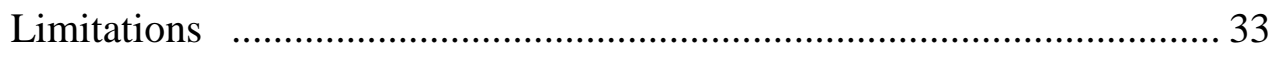

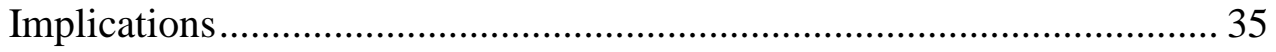

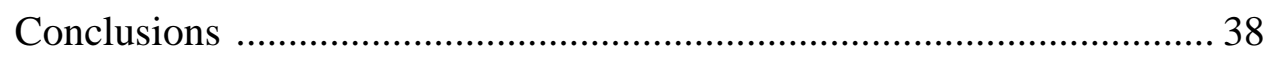

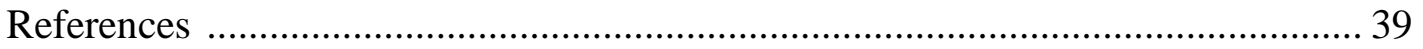




\section{List of Tables}

Table 1. Leadership Classification Results .............................................................. 50

Table 2. Means, Standard Deviations, and Inter-rater Agreement of Covariates

Table 3. Frequencies of Leader Fields and Speech Types

Table 4. Means, Standard Deviations, and Inter-rater Agreement of Study Variables

Table 5. Correlations and Reliabilities Among Study Variables ..................................... 54

Table 6. Discriminant Function Analysis Structure Matrix and Classification Results 55

Table 7. Regression Analyses for Communication Effectiveness, Follower Satisfaction, and Leader Effectiveness on Emotional Displays and Influence Tactics 


\begin{abstract}
The CIP Model of Leadership has received increased attention within the past decade. Research in this area has examined how leaders develop mental models, frame messages, communicate goals, and utilize political tactics to form relationships with followers and impact society in a meaningful way. However, discussion of how CIP leader types use emotions and influence tactics to influence followers and affect society is notably absent in the literature. To fill this gap, the current effort focuses on how charismatic, ideological, and pragmatic leaders differ in their use of emotional displays and influence tactics while maintaining similar levels of communication effectiveness, follower satisfaction, and leadership effectiveness. Results suggest that the emotional displays and influence tactics that leader use successfully discriminate between CIP leader types and create distinct leader styles. Implications of these findings are also discussed Keywords: CIP Model of Leadership, Emotional Displays, Authenticity, Emotional Volatility, Influence Tactics, Message Communication, Follower Satisfaction, Leadership Effectiveness
\end{abstract}


How Outstanding Leaders Lead with Affect: An Examination of Charismatic, Ideological, and Pragmatic Leaders

Scholars have attempted for decades to pinpoint exactly what makes a leader effective. In that time, researchers and practitioners have pointed to many variables that contribute to effective leadership, including traits like charisma and emotional stability (House, Curphy, \& House, 1994; Judge, Bono, Illies, \& Gerhardt, 2002; Shamir \& Howell, 1999); behaviors like supporting and encouraging followers (Howell \& Costly, 2001; Schaubroeck, Lan, \& Cha, 2007); and broader competencies like communication and enacting and managing change (Fleishmann, et al., 1992; Yukl, 2012). Throughout these perspectives on leadership effectiveness, there is a common thread - a thread that is continued in the current effort- that the emotions that leaders display, whether tied to their personal traits or to their message, are linked directly and indirectly to their success as a leader.

Within the past several decades, the idea that the presence of particular clusters of individual characteristics influences the effectiveness of leaders has resurfaced (Bass, 1985; Shamir, House, \& Arthur, 1993). Charismatic leadership and other positive forms of leadership have received the majority of attention, but other types of leadership that have shown an equally meaningful impact on society (i.e., ideological and pragmatic leadership) have started to gain traction in recent years (Mumford, 2006; Mumford and Van Doorn, 2001; Strange \& Mumford, 2002). Drawing on Weber's (1924) early conceptualization of leadership, Mumford (2006) explicated the CIP Model of Leadership. This model suggested that leaders create meaningful impact 
and have similar levels of effectiveness by using one of three broad pathways (Mumford, 2006, Mumford, Antes, Caughron, \& Friedrich, 2008).

Based on the theoretical dimensions associated with a leader's mental model (e.g., temporal orientation, locus of causation), Mumford and colleagues implicitly suggest that affect is one part of how outstanding leaders exert influence. In general, broader literature in the area of leadership and emotions has supported the notion that emotion plays a role in leadership communication (Riggio \& Lee, 2007), influencing followers (Fisher \& Ashkanasy, 2000; Groves, 2006; Yukl \& Falbe, 1990) and leadership effectiveness outcomes (Connelly \& Waples, 2008; Fisher \& Ashkanasy, 2000; McColl-Kennedy \& Anderson, 2002) but has not examined these relationships specifically with the three CIP leadership types in mind. As a result, there is a need to better understand how emotional displays play a role in each of the CIP pathways. Preliminary results from Hunter, Cushenbery, Thouroughgood, Johnson, and Ligon (2011) provided validation evidence for the dimensions encompassed in the CIP Model and suggested that positive and negative emotions should be included in the CIP as well. However, this study did not examine other important emotional indicators such as authenticity or emotional volatility. Additionally, the study's sample was wholly comprised of athletic coaches, which may limit generalizability. Aside from this initial indication of an emotional display dimension within the CIP Model, empirical research examining how emotional displays influence key variables and outcomes is lacking.

Drawing from previous research, this study primarily seeks to expand the CIP dimensions to include valence and types of emotional displays (e.g., positive, negative, 
authenticity, and emotional volatility) and provide a starting point for understanding how emotional displays impact leadership effectiveness, communication effectiveness, and follower satisfaction. Second, this study investigates three types of influence tactics that might vary by emotional state and CIP leader type. Specifically, this study explores how these tactics differ across leader styles and CIP leader type and how they are related to emotional displays. Finally, this study looks at the importance of emotional displays and influence tactics in predicting leadership effectiveness, communication effectiveness, and follower satisfaction through the lens of affective congruence (Newcombe \& Ashkanasy, 2002).

\section{The CIP Model of Leadership}

The CIP Model holds that, contrary to many perspectives of leadership effectiveness, there are multiple means through which leaders make meaningful impacts on society. Additionally, the CIP Model provides a concrete theoretical framework regarding how charismatic, ideological, and pragmatic leaders arrive at the same high-performing end state through different pathways. Specifically, Mumford (2006) highlights seven dimensions that differentiate between the prescriptive mental models of each leader type. These dimensions include time orientation (e.g., past, present, or future focus), types of experience utilized in developing mental models (e.g., positive, negative), nature of desired outcomes (e.g., positive, transcendent), number of desired outcomes (e.g., many, few), focus in mental model construction (e.g., internal, external), locus of causation (e.g., people, situations), and causation controllability (e.g., high, low). These dimensions work together to form unique combinations of three broad leader styles, which are discussed below. 


\section{Charismatic Leadership}

Charismatic leadership is defined as a social influence process that involves the formulation and articulation of an evocative vision, provides inspiration to motivate collective action, demonstrates sensitivity to environmental trends, and displays unconventional and perhaps personal risk-taking behavior (Mumford, 2006). Visions of charismatic leaders tend to point to the positive aspects of future goals while at the same time conveying relevant aspects of the present conditions (Strange \& Mumford, 2002). Theories focused on vision-based leadership such as transformational leadership (Bass, 1985; Burns, 1978) and charismatic leadership (Conger \& Kanugo, 1987; House, 1977; Shamir, et al, 1993) have been of particular interest in previous decades. The specific personality traits and behaviors associated with these theories differ somewhat, but the major underlying theme that charisma is a key component of leadership effectiveness remains constant. Charismatic leaders are generally excellent communicators (Holladay \& Coombs, 1994), but even follower attributions of leader charisma alone can be such a driving force in influencing followers and leadership outcomes that Yukl (2012) included charisma as a distinct type of power despite the existing classification of referent power, or power that relies upon personal liking.

\section{Ideological Leadership}

Contrary to charismatic leaders, ideological leaders overwhelmingly focus on past conditions, often an idealized version of the past, either real or imaginary. While ideological leaders articulate visions like their charismatic counterparts, ideological visions are predominantly defined by a commitment to their internalized, personal beliefs and values that generally result from negative life events or circumstances. The 
rigidity and narrowness of ideological leaders' mental models guides their entire worldview, which leads to selective interpretation or discounting of alternate views that contradict personal beliefs (Strange \& Mumford, 2005; Mumford, Espejo, Hunter, Bedell-Avers, Eubanks \& Connelly, 2007). It should be noted that while ideological leaders operate through different processes than charismatic leaders, ideological leaders have been linked to similar performance outcomes as charismatic leaders (Mumford, Strange, Gaddis, Licuanan, \& Scott, 2006).

\section{Pragmatic Leadership}

Pragmatic leaders use any tactics or problem-solving skills that are necessary to resolve existing issues (Mumford \& Van Doorn, 2001). Pragmatic leaders are concerned with characteristics of the present situation and stress neither goals nor causes in the formation of their mental modes. Rather, problem solutions are largely dependent on the complexity of the issue. These leaders are much more interested in scanning their environment and gathering information to find key causes than relying on vision-based communication or personal beliefs. Unsurprisingly, pragmatic leaders tend to rely on some influence tactics over others such as rational persuasion over inspirational appeals (Mumford et al, 2006; Yukl, 2012). Further, pragmatic leaders use facts, evidence, and logical analysis as a means of communicating with others, rather than highlighting positive or negative elements of the past or future (Mumford, et al, 2006).

\section{Emotional Displays and CIP Leader Type}

The ways in which leaders display and control emotion has received considerable attention in recent years. The emotions that leaders choose to display or 
not relays valuable information to followers regarding the leader's personal feelings (Knutson, 1996) as well as setting and adjusting expectations for social interactions within the group or organization (Cacioppo \& Gardner, 1999; Keltner \& Haidt, 1999; Schwarz \& Clore, 1983). This can occur via positive or negative valence emotional displays, but this information can also be gleaned from perceptions of leader authenticity and volatility (Hogan, et al., 1994; Judge, et al., 2002). Empirical examination of the seven dimensions of the CIP Model suggests that the various pathways would also likely use emotional displays in differential ways (Hunter, et al., 2011; Mumford, 2006; Strange \& Mumford, 2005; Van Doorn \& Mumford, 2001). For instance, charismatic leaders tend to focus on looking to the future, and their messages typically highlight the potentially positive events that will occur if their many positive goals are met. Conversely, ideological leaders set their sights on returning to an idealized past, either real or imagined. Ideologues craft messages that articulate a rigid, internalized belief structure while simultaneously making note of the present consequences associated with what the leader perceives as a negative event. Pragmatics focus on present-circumstances and operate within constraints of the current environment. As such, they tend to be much more malleable in their approach to solutions than their counterparts. Considering these descriptions and initial evidence of an emotional component to outstanding leadership from Hunter and colleagues (2011), we propose the following set of hypotheses:

H1: Charismatic leaders will display more positive emotion than ideological leaders or pragmatic leaders 


\section{H2: Ideological leaders will display more negative emotion than charismatic}

\section{leaders or pragmatic leaders}

Research in the area of authenticity suggests that more authentic leaders are more future-oriented and more positive overall (Avolio \& Gardner, 2005; Mitchie \& Gooty, 2005). However, research in this area has tended to have an optimistic bias and retains the idea that charisma and positive emotions are more indicative of leadership effectiveness than other displays of emotion (Gooty, Connelly, Griffith, \& Gupta, 2010). Many previous efforts have considered authenticity only through the lens of emotion valence, but others contend that authenticity is broader- being true to oneself and displaying genuine emotion depending on the situation rather than adhering to positive displays and interactions (Gardner, Avolio, Luthans, May, Walumbwa, 2005; Novicevic, Harvey, Ronald, \& Brown-Radford, 2006). This is particularly relevant given that followers who do not have highly crystallized beliefs in line with a leader's message may perceive a leader's emotional displays as manipulative or exaggerated (Eberly \& Fong, 2010). In fact, Trilling and Trilling (1972) found that leaders who do not heavily rely on emotional displays to convey their message were perceived as more sincere than leaders more apt to utilize positive or negative emotions. As such, we propose the following:

H3: Pragmatic leaders will be perceived as more authentic than ideological leaders and charismatic leaders.

Emotional volatility is often discussed in the context of leadership derailing

(Carson, Shanock, Heggestad, Andrew, Pugh, \& Walter, 2012; Kaiser \& Hogan, 2007; Yukl, 2012), and conceptualization of the opposite idea, emotional stability, is often 
related to leadership emergence and effectiveness (Hogan, Curphy, \& Hogan, 1994; Hogan \& Kaiser, 2005; Judge, Bono \& Illies, 2002). Leader types that rely on emotional displays often, such as charismatic and ideological leaders, would be the most likely leader types to be perceived as emotionally volatile, but Judge and Bono (2000) found no relationship between charismatic leaders and neuroticism. Indeed, charismatics tend to be consistent in their displays of positive emotions (Bono \& Illies, 2006; Erez, Misangyi, Johnson, LePine, \& Halverson, 2008). Further, volatility is generally associated with negative emotions such as anger and fear (Watson \& Clark, 1984; Watson, 2000). In fact, Keltner (1994) found that neuroticism predicted displays of anger, contempt, and fear - emotions that ideological leaders would be more likely to exhibit. Therefore, we propose the following hypothesis:

H4: Emotional volatility will be perceived to be higher in ideological leaders than charismatic leaders and pragmatic leaders.

\section{Emotional Displays and Influence Tactics}

Much of the communicating a leader does involves the element of influence persuading people to work together, to achieve common goals, and to accomplish more than they thought they could (Yukl, 2012). As such, messages that leaders deliver to followers are constructed to be persuasive (Yukl \& Tracey, 1992). Because the CIP Model holds that leaders are equally impactful in their pursuits, it's likely that the different leader types favor influence tactics that enhance their overall messages and adhere to the leader's mental model (Mumford, 2006). Bass (1985) contends that charismatic and transformational leaders tend to use positive messages oriented toward the future. To highlight these attributes, charismatic leaders tended to use 
inspirational appeals. Ideological leaders, on the other hand, tended to focus on previous failure and negative events in their plan formation and goal communication (Strange \& Mumford, 2002; Strange and Mumford, 2005). As such, these leaders will likely resort to pressure and blaming and attacking of others to influence their followers (Rejai, 1991). Finally, pragmatic leaders take a more utilitarian approach, and, as such, they likely use more objective means to persuade others, such as rational persuasion (Mumford \& Van Doorn, 2001; Yorges, Weiss, \& Strickland, 1999). Bearing these things in mind, we propose the following set of hypotheses:

H5: Charismatic leaders will use more positive or sanctioned tactics than ideological leaders or pragmatic leaders.

H6: Ideological leaders will use more negative or unsanctioned tactics than charismatic leaders or pragmatic leaders.

H7: Pragmatic leaders will use more logical tactics than charismatic leaders or ideological leaders.

\section{Leadership Outcomes}

Broader literature in leadership and emotions has shown that emotions and influence tactics influence leader effectiveness in terms of communicating with followers and leader performance (Ahearn, Ferris, Hochwater, Douglas, \& Ammeter, 2004; Avolio, Walumbwa, \& Weber, 2009). However, previous research has focused most of its attention to positive outcomes associated with positive emotional displays (Gooty, et al., 2010). However, the CIP Model suggests that overall leadership effectiveness variables are relatively similar despite the seemingly different emotional displays that leaders utilize to meet their goals (Mumford, 2006). As such, we expect 
to replicate these overall trends in leadership effectiveness outcomes. However, it is unclear how emotions and influence tactics jointly influence leader outcomes in outstanding leaders. To investigate this, several areas linked to successful leadership are examined, including communication effectiveness, follower satisfaction, and leadership effectiveness.

\section{Communication Effectiveness}

Communication with followers is a critical component of leader performance (Riggio, Riggio, Salinas, \& Cole, 2003). Communication effectiveness can be assessed based on various objective criteria such as message clarity, message specificity, message flow, and articulation (Farache, 1978; Thayer \& Goldhaber, 1988). However, all of these things being equal, the way in which a speech or address is delivered can change the way followers respond (Groves, 2006). The intent behind leader communication, whether it is through a speech, address, interview, email, or editorial, is to connect with followers and convey important organizational information. In fact, Bass (1988) contends that the core competency of leaders is to effectively articulate a shared purpose and communicate goals to meet those ends. As such, it is essential that leaders communicate effectively, both in the objective sense but also in such a way that communicates the message to followers in the specific tone that leaders intend.

The influence tactics that leaders use to articulate their messages can spur followers to pick up their cause. As such, influence tactics may be largely incorporated into the message content itself, making influence tactics a more central component to the arguments that leaders make (Hunter, et al, 2011; Mumford, 2006). Incorporating influence tactics relevant to leader's mental model is a critical first step in 
persuasiveness (Strange \& Mumford, 2005, Strange \& Mumford, 2002; Kipnis \& Schmidt, 1998). For instance, charismatic leaders would likely deliver a futureoriented, vision-based message whereas pragmatic leaders would focus on solving the problem at hand with little emotional display.

The fervor with which a speech is delivered or the tone the leader takes during the speech can be influential on its own (Waples \& Connelly, 2008). In fact, research in the communication areas has long suggested that specific intonation patterns are indicative of particular emotions and emotional intensity, both of which offer clues to the major components of leader communication (Fonagy \& Magdics, 1963; Pakosz, 1983). Chaiken's (1987) heuristic-systematic model suggests that individuals process persuasive elements within a message concurrently in two ways - peripherally and centrally. In other words, individuals base their attitudes and beliefs about a particular message on both the quality of the message and heuristic response to cues about which individuals already have established attitudes (Chaiken, Liberman, \& Eagly, 1989). For instance, considering the substantive contents of a leader's message (e.g., policies) would entail central processing. Reacting automatically to the leader's political affiliation or to the American flag hanging on the podium from which the leader is speaking would likely trigger a heuristic, or peripheral, response. The use of emotional evocative images, text, or audio in the context of an event or situation in which followers are highly invested or with which they deeply identify would likely elicit a persuasive, automatic response (Dilliard. \& Anderson, 2004; Rogers, 1975). Given the usefulness of emotional displays to convey information quickly through vocal intonation, intensity, or other nonverbal means like facial expressions, it's likely that 
vision-based and values-based CIP leaders would rely on these things to convey their message to followers.

Several of the influence tactics within the taxonomy developed by Yukl (2012) are explicitly emotions-based (e.g., inspirational appeals). Others, such as personal appeals, collaboration, apprising, ingratiation, coercion, and coalition building have an implicit expectation that certain emotions are more appropriate for use with a specific influence tactic than others. For instance, positive emotions would likely not be paired with coercion, and negative emotions may not be useful when attempting to use apprising. Furthermore, pairing positive or negative emotional displays with influence tactics that do not match with the valance of displayed emotion may lessen perceptions of authenticity and increase perceptions of volatility. As a result, the affective incongruence between emotional display and leader communication may overshadow the leader's message (Newcombe \& Ashkanasy, 2002).

When there is congruence between type of influence tactic used and emotional displays, communication effectiveness may be better because the concurrent use of matching tactics and emotions are sending a clear message that has a consistent affective valance (Connelly, Gaddis, \& Helton-Fauth, 2002; Newcombe \& Ashkanasy, 2002; Waples \& Connelly, 2008). While much research supports this notion specifically with regard to positive affective congruence, Bucy (2000) expands affective congruence into negative displays. In an empirical study of viewers' responses to a presidential address, Bucy found that when leaders responded to negative events with emotions that viewers perceived to be appropriate (e.g., negative), 
leaders were evaluated as more credible, trustworthy, and effective than presidents who displayed positive emotions following a negative event.

Given that charismatic leaders appear to favor the use of positive emotions, it appears likely that charismatic leaders would also tend to use influence tactics in conjunction with positive emotions such as inspiration appeals and future projection. Ideological leaders, on the other hand, would likely tend to use influence tactics in tandem with negative emotions such as pressure and attacking and blaming others. Pragmatic leaders, as noted by Mumford and colleagues (2006), tend to stick to influence tactics that accentuate logic and rational thinking, such as rational persuasion and exchanges. Therefore, we propose the following:

H8: The joint influence of emotions and influence tactics will account for significant variance beyond main effects of emotional displays and influence tactics in predicting communication effectiveness such that an emotional display-influence tactics match (e.g., positive/positive, negative/negative) will positively predict communication effectiveness and a mismatch will negative predict communication effectiveness.

\section{Follower Satisfaction}

Positive interactions between leaders and followers have also played an important role in achieving leadership goals (Cogliser, Schriesheim, Scandura, \& Gardner, 2009; Graen \& Uhl-Bien, 1995). Follower satisfaction and other constructs that act as a proxy of satisfaction, such as mutual trust, loyalty to the leader, and liking of the leader (Dansereau, Graen, \& Haga, 1975), are based on the relationship that followers have or expect to have with their leaders. For charismatic and ideological 
leaders, closeness of relationships between leaders and followers plays a large role in how loyal and trusting followers are. Leaders also benefit from this relationship because they rely on followers to complete certain tasks for them and implement their goals (Mumford, 2006; Uhl-Bien, 1979). Expression of emotions that are in line with follower expectation, then, would play a role in developing this relationship. Attempting to influence followers in ways that are detrimental to trust and mutual respect may be particularly harmful to follower satisfaction except in rare cases (Yukl, 2012).

It is often necessary for leaders to rely on large groups of followers to accomplish a task or reach a collective goal (Bass, 1985; Yukl, 2012). This is especially the case for charismatic and ideological leaders, which also appear to be the CIP leader types that are more likely to utilize emotional displays overall and, more specifically, use emotions to influence followers and create highly cohesive groups based on a set of shared values (Mumford, 2006). Specifically, Conger, Kanungo, and Menon (2000) showed support for high quality charismatic leader-follower relationships, and Strange and Mumford (2002) observed close relationships between ideological leaders and their followers. Pragmatics, on the other hand, have a different relationship with followers, opting to build strong relationships with a few trusted, knowledgeable, and well-connected elites (Lemann, 2000). Rather than relying on a large group of followers to implement goals and plans, pragmatic leaders build small groups, of which they are often a member, to tackle problem solving efforts (Mumford \& Van Doorn, 2002). However, followers may still show trust in a pragmatic leader given their ability to problem solve and resolve issues (Mumford \& Van Doorn, 2001). 
As noted, emotion itself can be influential and serve as a cue to how the leader is feeling (Knutson, 1996). Followers who have particularly high levels of follower satisfaction may be more susceptible to the leader's emotional displays or a leader's attempt at affective congruence (e.g., perceived as empathy; Illies, Curseu, Dimotakis, \& Spitzmuller, 2012; Liu \& Perrewe, 2006). Indeed, high follower satisfaction is often associated with charismatic leadership (Conger, et al., 2000), and dissatisfaction and conflict are rare within groups with ideological leaders given the close relationship between ideological leaders and their followers (Mumford, et al., 2007; Strange \& Mumford, 2002). Bearing these things in mind, we propose the following: H9: The joint influence of emotions and influence tactics will account for significant variance beyond the main effects of emotional displays and influence tactics in predicting follower satisfaction such that an emotional display-influence tactics match (e.g., positive/positive, negative/negative) will positively predict follower satisfaction and a mismatch will negative predict follower satisfaction.

\section{Leadership Effectiveness}

The trend in the leadership literature is fairly direct with regard to perceptions of leader effectiveness and leader emotional displays. In general, leaders who display positive emotions and positive influence tactics (e.g., inspirational appeals) tend to be viewed as more effective, particularly in terms of exerting influence on large groups and developing long-term working relationships. (Gooty, et al., 2010, Illies, et al., 2012). More specifically, leaders who displayed active, positive emotions (i.e., emotions the result in a higher occurrence of action) were viewed as more effective 
than those who showed passive, positive emotions (i.e., emotions the result in a lower occurrence of action) in terms of vision implementation and leader effectiveness (Connelly \& Ruark, 2010). These results clearly follow previous research in the area of charismatic leadership theory (House, 1977; Shamir et al., 1993).

However, this relationship becomes more complicated when taking into consideration empirical evidence of the importance of leader emotional displays matching the valence and intonation of a leader's message (Newcombe \& Ashkanasy, 2002) and the importance of the leader's emotional displays matching followers' assessments of the situation (Damen, Van Knippenberg, \& Van Knippenberg, 2008). The use of appropriate emotions, then, appears to outweigh the use of one valence of emotions over the other. Van Knippenberg, van Knippenberg, De Cremer, \& Hogg (2004) suggest that in instances where the follower's expectations are influential in shaping how a leader should interact, it is more useful to examine the issue of followership before making a determination of which leader emotional display is appropriate. Further, in the appropriate context, negative emotions have been found to contribute positively to follower perceptions of leader effectiveness (Bucy, 2000, Tiedens, 2001, Van Kleef, De Dreu, \& Manstead, 2004). Additionally, high levels of leadership effectiveness have also been found for logical influence tactics rather than emotional appeals in various situations (Kipnis \& Schmidt, 1988; Yukl \& Tracey, 2003).

Bearing this in mind, it may be that the affective match between emotional displays and the influence tactics that leaders use is more important than strictly the use of positive or negative emotional displays because the match indicates authenticity. 
In fact, Eberly and Fong (2010) found that perceptions of leader sincerity were more important than valance.

Therefore, propose the following questions:

H10: The joint influence of emotions and influence tactics will account for significant variance beyond main effects of emotional displays and influence tactics in predicting leadership effectiveness such that an emotional displayinfluence tactics match (e.g., positive/positive, negative/negative) will positively predict leadership effectiveness and a mismatch will negative predict leadership effectiveness.

\section{Method}

This study was based on a sample of 93 historically significant leaders (32 charismatic leaders, 30 ideological leaders, and 31 pragmatic leaders) from the mid to late $20^{\text {th }}$ though early $21^{\text {st }}$ century that held a variety of leadership positions (e.g., government, business, military, etc.). Leaders selected for inclusion in this study fell distinctly into one of the three outstanding leadership classifications. Leaders must have unambiguously been identified as charismatic, pragmatic, or ideological through previous investigation (cf., Mumford, 2006) or rated as such by trained judges for inclusion in the sample. The sample was split into thirds with 30 leaders selected for each type of outstanding leadership. This sample size was predetermined to provide satisfactory levels of power for predicting differences among the three categories.

\section{Sample}

Regarding selection of leaders for inclusion in the study, several key criteria must be noted. First, leaders must have held a position of power within the $20^{\text {th }}$ and/or 
early $21^{\text {st }}$ centuries for two reasons. Given the importance of leader emotional displays, including nonverbal displays, in this study, only leaders with publicly viewable speeches were included. Prior to the early $20^{\text {th }}$ century, videotaping of speeches was simply not a technological option. Additionally, biographical information written before World War II was subject to much less scrutiny than those written afterward. Because this study is reliant on verifiable biographical information, only leaders tied to data from academic and trustworthy sources (e.g., book reviews) were included. Second, it was essential that leaders included in the sample could be rated in terms of their impact and effectiveness. In other words, if the outcomes of a leader's actions could not be wholly assessed, the leader was removed from consideration. Third, a concerted effort was made to include a diverse group of leaders. This included sampling from different fields (e.g., business, social movements, military, government), different leadership positions (e.g., President, civil rights leader, Prime Minister, congressional leader), and including male and female leaders. When possible, Western and non-Western leaders were included in the sample as well. While the sample is highly diverse across all the categories, no attempt was made to equally distribute field, positions, or gender within each category.

Identification of leaders for inclusion in the study required several considerations. First, a list of potential candidates for inclusion was developed. This list included any leaders listed as historically notable regarding business (e.g., Fortune 100, Forbes, and Economist profiles), social and political movements (e.g., general history textbooks and biographical websites), and government and military (e.g., Presidential and congressional archives, general history textbooks, and biographical 
websites). This initial list yielded 304 leaders. Then, the initial list of leaders was narrowed to 236 as a result of investigation of academic biographical information. Leaders retained for inclusion must have had at least one academic biographical account available, however, leaders who were the subject of multiple biographies were given preferential standing for inclusion. Multiple accounts amount to more comparisons of consistency in biographical information and also provided validation in regard to the impact of the leader in question. Leaders with numerous biographies were generally those with a strong, lasting legacy (e.g., Franklin D. Roosevelt). Next, speeches available for public viewing (e.g., American Rhetoric Speech Project, Mount Mercy University Speech Directory, American and international governmental historical associations, and Presidential State of the Union Archives) limited the pool of leaders to 163 .

Six judges, all doctoral candidates in industrial-organizational psychology, then screened this list of potential candidates. Judges were given access to biographical sketches of each of the leaders that coincided with two time periods: the time during which the leader rose to power and the time during which the leader was in power. Based on this information, judges classified the leaders based on a set of dimensions that makes clear delineations between charismatic, ideological, and pragmatic leaders (Mumford, 2006). These dimensions include time frame, types of experience used, nature and number of outcomes sought, focus in model causation, and locus and controllability of causation. A leader was classified as charismatic if they communicated a future-focused vision that incorporated multiple, directive, positive goals based on social needs or obstacles (e.g., Martin Luther King, Jr.). A 
leader was classified as ideological if they communicated a transcendent vision of an idealized past based on personal beliefs in which previous negative experiences are stressed as causes for action (e.g., Billy Graham). A leader was classified as pragmatic if they focused on problem solving, reaching viable solutions, and overcoming the obstacles of the present (e.g., Dwight D. Eisenhower).

Adhering to these criteria, judges agreed on $90 \%$ of their leader classifications. In the cases that judges did not agree sufficiently in their assignment to a specific category, the leader was removed from consideration. While removing candidates from the list is not ideal, it is necessary to avoid incorporation of leaders that may be of a hybridized type (i.e., both charismatic and ideological). The final list of 93 leaders is presented in Table 1. While this list is meant to be as comprehensive as possible, several limitations of sampling must be addressed. First, the majority of leaders in the sample are male. This is largely due to the timeframe during which we are sampling. Men held the majority of leadership positions during this time, and leadership positions for women were not as visible or as readily available. Nonetheless, the sample does include several women who have influenced and impacted others through a position of power (e.g., Gloria Steinem). Second, leaders from the same fields show some likelihood of grouping into the same category. For instance, leaders identified from the field of business tended to be pragmatic, whereas political leaders tended to be classified as ideological. This is not particularly surprising given the nature of influence, the targeted audience, and the anticipated outcomes of leaders across the different arenas. 


\section{Data Sources}

Two data sources, biographical data and speech excerpts, were considered in evaluating predictors and criteria of each leader. The procedures undertaken to retrieve and select this data are detailed in the following sections.

\section{Biography Selection}

A reference search in a southwestern university and several local libraries in the area resulted in the initial identification of potential biographies. These biographies were then reviewed for several criteria.

In many cases, several biographies for the same leader were found to contain satisfactory information for content coding. In these cases, three trained undergraduate students reviewed each biography with regard to the following criteria:

1. Did the biography provide useful and detailed information regarding all the key variables of interest (e.g., influence tactics)?

2. Did the biography provide objective and comprehensive evaluation of the leaders impact, contributions, and effectiveness?

With regard to these questions, specific instances of objective and comprehensive evaluations are borne in mind. First, the biographies must contain information describing the various careers and positions of power of each leader. Biographies that contained only information regarding a limited timeframe (e.g., Reagan during the Cold War) were removed from consideration. Second, biographies must contain factually correct and academically sourced information. In other words, the biographical information presented must adhere to historical accounts in general history textbooks and rely on and reference primary sources of information. 
Biographies that were subjective, journalistic, or sensational in nature were excluded from further examination.

The biography that resulted in both the most comprehensive and objective information on both points of consideration was used for content analysis. In the event that none of the biographies reviewed met satisfactory levels, additional biographies were sought for review. If this search was unfruitful or the additional sources were unsatisfactory, the leader was dropped from the list. Leaders on the list that contained less biographical information sources (i.e., only one biography) were revisited and replaced those removed from the list when necessary. In each case, biographical information was again reviewed to insure that the data was comprehensive and objective in nature before selecting the final biography.

Given that content analysis of the biographical data was focused on several key areas, chapters that best reflected these times were selected for further investigation by three judges. These chapters fell into three categories: the "rise to power" chapter(s), the "pinnacle of power" chapter(s), and the epilogue and prologue chapters. Each of these chapters provides valuable insights into the various areas of interest. Specifically, the rise to power and pinnacle of power chapters generally detailed the means through which each leader exerted influence over others and how they communicated their goals and vision. The epilogue and prologue chapters provide summations of the leadership contributions and accomplishments. Content coded sections associated with each biography were, on average, approximately 23 pages. 


\section{Speech Excerpt Selection}

Following initial selection of biographical information, speech excerpts were selected for each leader. Excerpts were selected from websites that allow public viewing of leader speeches (e.g., American Rhetoric Speech Project). Not all possible speeches of each leader were content analyzed. Rather, 15 minutes sections of each speech were included in order to make more consistent, informed judgments concerning the variables of interest. In selecting speech excerpts, several things were considered. First, every speech must focus on the leader from a frontal view such that nonverbal emotional displays are visible to the viewer. Second, viewable sections of speeches must be consistent across all the speeches examined. In order to achieve this, three 5 minute sections were recorded for review, or, in the event that the speech was 15 minutes or less, the entire speech was retained for viewing. For instance, in every speech, the judge was required to view the first 5 minutes of the speech, the middle 5 minutes of the speech, and the final 5 minutes of the speech. The timestamps associated with each of these pieces was compiled for coders ahead of time. This approach allowed for maximum controllability in terms of viewing desired content.

In several cases, multiple speeches were available for public viewing. In these cases, several key considerations were made in selecting which leader speeches would be retained for coding. First, speeches that were considered to be part of the legacy of the leader were given priority over those that were not (e.g., "New Frontier" speech of John F. Kennedy v. State of the Union, 1963). Second, speeches that spent a majority of the time panning across the audience or otherwise focused on other aspects of the situation beside the leader did not allow for substantial viewing of the leader's facial 
expressions and other nonverbal forms of communication. In those cases, not all variables could be coded, and the speech was removed from consideration. Finally, if other variables resulted in less than ideal coding scenarios, such as the leader being too far away from the camera to accurately judge facial expressions, the video of the speech was removed from consideration.

As with biographical information, speeches were selected from two particular time periods of interest, the rise to power period and pinnacle of power period. It was during these time periods that leaders would likely exert the greatest influence on others, and, therefore, these time periods are those that are of the most significance in terms of speech delivery and vision communication.

\section{Content Coding}

Following materials selection, the process of content coding of predictors, outcomes, and control variables began. Benchmark ratings scales were developed based upon an extensive literature review of the constructs of interest as discussed in the introduction and were compiled for review. A mix of graduate and undergraduate judges were required to complete a 2 -week, 10 hour frame of reference training program (Bernardin \& Buckley, 1981) in order to familiarize them with coding procedures, coding materials, variables of interest, and various rating errors that are likely to occur during the coding process. Specifically, judges were provided with the definitions of all dimensions they would be responsible for evaluating. After the dimensions were clearly understood, behavioral markers of low, medium, and high manifestations of each dimension were presented and discussed. Upon completion of the initial training program, judges were presented with material selected from 
biographies and leader speeches on which to practice applying the benchmark ratings scales for each dimension. After completing this task independently, the judges would again convene and discuss any discrepancies within the group. When discrepancies arose, clarification and feedback on the dimensions would be offered, and discussion would continue until a consensus was reached regarding application of the dimensions in those cases. This process was iterative. Several weeks of practice coding were necessary for all judges to reach a consistently adequate level of inter-rater agreement ranging from .61 to .95 with an average of .80 ( $\mathrm{r}^{*} \mathrm{wg}$; James, Demaree, \& Wolf, 1984). In total, five judges coded predictor variables, and six judges coded criteria variables. Final inter-rater agreement associated with all variables included in analyses is presented in Table 3.

\section{Predictors}

Emotional Displays. Based on previous findings regarding nonverbal emotional displays (Knapp \& Hall, 2009), the importance of emotional valance and intensity in communication (Bachorowski, 1994, 1995, 1999), and the theoretical underpinnings of the importance of emotional display in both ideological and charismatic leadership (Mumford, 2006; Strange \& Mumford, 2002, 2005), eight metrics associated with emotional display were developed for evaluation from both speech excerpts and biographical information. These metrics were collapsed into four rationally determined variables - positive emotional display $(\alpha=.89$; positive tone, positive intensity, and positive nonverbal expression), negative emotional display ( $\alpha$ $=.90 ;$ negative tone, negative intensity, and negative nonverbal expression), emotional authenticity $\left(r^{* \mathrm{wg}}=.83\right)$, and emotional volatility $\left(r^{* \mathrm{wg}}=.73\right)$. With the exception of 
emotional volatility, all emotional display variables were evaluated based on speech excerpts on a 5-point Likert scale, with1 representing a low instance of the dimension and 5 representing a high manifestation of the metric. While emotional volatility was evaluated based on the same Likert scale, metrics were evaluated based on biographical information within the rise to power and pinnacle of power chapters.

Influence Tactics. Outstanding leadership requires that leaders engage in influence tactics and political behavior to gain support from followers and allies to pursue a goal or agenda (Yukl, 2012; Zanzi \& O’Neill, 2001). In order to further investigate the ways in which emotional displays interact with influence tactics, several dimensions from Yukl's (2009) taxonomy will be explored. These five influence tactics were collapsed into three rationally determined dimensions of influence tactics: positive or sanctioned tactics $(\alpha=.43$; inspirational appeals and future projection), negative or unsanctioned tactics $(\alpha=.50$; pressure and blaming or attacking others), and logical tactics $\left(r^{* \mathrm{wg}}=.69\right.$; rational persuasion $)$. All influence tactics metrics were evaluated based on biographical information within the rise to power and pinnacle of power chapters on a 5-point Likert scale on which 1 represents a low instance of the metric and 5 represents a high manifestation of the metric.

\section{Criteria}

Communication Effectiveness. Leaders in highly visible positions of power often rely on mass communication to perpetuate a cause or issue. Given the previous findings on communication effectiveness (Fiedler, 1971; Jablin, 1979) and vision formation (Calantone \& Schatzel, 2000; Strange \& Mumford, 2002), several dimensions have been established for review in this study. These four metrics were 
collapsed into one rationally determined dimension of communication effectiveness ( $\alpha$ $=.75$; message clarity, message specificity, message flow, and articulation of the message). All communication effectiveness variables were evaluated based on speech excerpts on a 5-point Likert scale on which 1 represents a low instance of the metric and 5 represents a high manifestation of the metric.

Follower Satisfaction. Because followers play such a distinguished role in supporting leaders and promoting a leader's agenda, understanding the ways that leaders use emotional displays to increase follower satisfaction may shed light on why some outstanding leaders utilize some displays over others (Dansereau et al, 1975). The five satisfaction metrics were collapsed into one rationally determined dimension of follower satisfaction $(\alpha=.92$; liking, trust, loyalty, similarity, and support. All follower satisfaction variables were evaluated based on biographical information from the epilogue and prologue chapters. Dimensions were rated on a 5-point Likert scale on which 1 represents a low instance of the metric and 5 represents a high manifestation of the metric.

Leader Effectiveness. Given the importance of both subjective and objective evaluations of leader effectiveness, the four leader effectiveness metrics were collapsed into two rationally determined variables: task-based leader effectiveness ( $\alpha$ $=.69$; strategic thinking and results achievement) and relationship-based leader effectiveness $(\alpha=.57$; influencing others and cultivation of productive working relationships). With the exception of the strategic thinking dimension, all leader effectiveness metrics were evaluated based on biographical information from the epilogue and prologue chapters. Strategic effectiveness was evaluated based on the 
rise to power and pinnacle of power chapters. All metrics were rated on a 5-point Likert scale on which 1 represents a low instance of the metric and 5 represents a high manifestation of the metric.

\section{Control Variables}

A number of additional measures were obtained as control variables. These measures were intended to take into account the various extraneous variables that would lessen the likelihood that casual inferences based on the data are sound. Because some variables will inevitably covary with manipulations (e.g., business leaders will have smaller audience sizes than political leaders), controlling these variables will allow a clearer picture of outstanding leaders to emerge. Control variables were coded both from the speech excerpts and the biographical information. Variables evaluated based on speeches include variables such as type of speech, audience size, and length of speech. Measures evaluated from biographical information include variables such as leader age during pinnacle of power, leader field, leader gender, number and frequency of public appearances, Western/non-Western leader, level of detail in biographies, biographer evaluation of leader, and leader power orientation. In order to avoid method bias, judges tasked with coding biographical excerpts coded only control variables associated with biographies (e.g., author evaluation, level of detail in biographies). Similarly, judges tasked with coding leader speeches coded only control variables associated with speeches (e.g., length of speech, audience size). The nature of response to the control measures varied depending on the construct (e.g., ratings vs. counts). See Table 2 for means and standard deviations by 
CIP leadership type and Table 3 for frequencies associated with speech type and leader field by CIP leadership type.

\section{Results}

\section{Analyses}

To investigate the similarities and differences between charismatic, ideological, and pragmatic leaders and the relationships among key variables of interest, data were analyzed using several data analytic techniques. First, descriptive statistics and correlations were examined. See Table 4 for means, standard deviations, and interrater agreement coefficients by CIP leadership type and Table 5 for correlations among study variables. Second, mean differences between the CIP leadership types were examined using a Multivariate Analysis of Covariance (MANCOVA). Third, the data were analyzed using a discriminant function analysis (DFA) to determine which components of the leaders' actions strongly predicted group membership among the three leader classifications. Only non-zero, high loading factors $(<.20)$ were retained in final analyses. Finally, regression analyses were used to examine how emotional displays and influence tactics work in combination to predict the three main leadership outcomes (i.e., communication effectiveness, follower satisfaction, and leadership effectiveness).

\section{Hypothesis Testing}

CIP Leader Type Mean Differences

A MANCOVA revealed that CIP leader type was a significant main effect

$\left(F(24,158)=2.87, p<.001, \eta_{p}^{2}=.30\right)$ in differentiating emotional displays and influence tactics in expected ways, but many of the outcome variables were not 
significantly different across the leadership types. This finding replicates similar patterns of outcome variables in previous CIP Model research (Mumford, 2006). Examination of univariate effects showed that charismatic leaders displayed more positive emotion $(M=2.64, S D=.87)$ than ideological leaders $(M=2.07, S D=.87)$ and pragmatic leaders $(M=2.10, S D=.82), F(2,89)=4.29, p=.02, \eta^{2}=.09$. Ideological leaders $(M=2.22, S D=.92)$ also showed more negative emotional displays that charismatic leaders $(M=1.59, S D=.55)$ and pragmatic leaders $(M=$ $1.57, S D=.63), F(2,89)=4.04, p=.02, \eta^{2}=.08$. With respect to authenticity, pragmatic leaders $(M=4.35, S D=.35)$ were perceived as more authentic than charismatic leaders $(M=3.93, S D=.80)$ and ideological leaders $(M=4.17, S D=.42)$, $F(2,89)=4.79, p=.01, \eta^{2}{ }_{p}=.10$. Finally, ideological leaders $(M=3.07, S D=1.06)$ were perceived as marginally more emotionally volatile than charismatic leaders ( $M=$ 2.53, $S D=1.00)$ and pragmatic leaders $(M=2.67, S D=.99), F(2,89)=2.38, p$ $=.10, \eta_{p}^{2}=.05$. In sum, these findings support hypotheses $1,2,3$, and 4 .

Univariate analyses also showed expected patterns of mean differences among influence tactics. Charismatic leaders $(M=2.70, S D=.85)$ used more positive tactics than ideological leaders $(M=2.47, S D=.58)$ or pragmatic leaders $(M=2.26, S D$ $=.61), F(2,89)=3.14, p=.05, \eta_{p}^{2}=.07$. Ideological leaders $(M=2.22, S D=.92)$ used more negative tactics than charismatic leaders $(M=1.59, S D=.55)$ and pragmatic leaders. $(M=1.57, S D=.63), F(2,89)=5.52, p=.01, \eta^{2}=.11$. Finally, pragmatic leaders $(M=2.49, S D=.92)$ used more logical reasoning influence tactics than charismatic leaders $(M=1.88, S D=.98)$ and ideological leaders $(M=2.13, S D$ 
$=.92), F(2,89)=3.00, p=.05, \eta^{2}{ }_{p}=.06$. Taken together, these hypotheses support hypotheses 5, 6, and 7 .

Examination of outcomes measures associated with outstanding leadership were relatively stable across the leadership types. Charismatic leaders, ideological leaders, and pragmatic leaders showed similar levels of communication effectiveness (charismatic leaders, $M=3.67, S D=.41$; ideological leaders, $M=3.65, S D=.53$; and pragmatic leaders, $M=3.65, S D=.57$ ), follower satisfaction (charismatic leaders, $M=3.94, S D=.58$; ideological leaders, $M=3.70, S D=.67$; and pragmatic leaders, $M=3.73, S D=.62$ ), and overall leadership effectiveness (charismatic leaders, $M=$ 4.06, $S D=.47$; ideological leaders, $M=3.82, S D=.50$; and pragmatic leaders, $M=$ $3.93, S D=.50)$. Interestingly, when leadership effectiveness was examined based on its relevance to task-oriented or relationship-oriented behavior, margin differences between the CIP leadership types started to emerge. Pragmatic leaders $(M=4.13, S D$ $=.51)$ were marginally more effective than charismatic leaders $(M=3.98, S D=.42)$ and ideological leaders $(\mathrm{M}=3.74, S D=.51)$ when only task-oriented variables were examined, $F(2,89)=2.39, p=.10, \eta_{p}^{2}=.05$. Conversely, charismatic leaders $(M=$ $4.00, S D=.55)$ were marginally more effective than ideological leaders $(M=3.78$, $S D=.46)$ and pragmatic leaders $(M=3.78, S D=.92)$ when only relationshiporiented variables were examined, $F(2,89)=2.51, p=.09, \eta^{2}{ }_{p}=.05$.

\section{CIP Leader Type Emotional Styles}

Next, DFAs were used to examine how emotional styles (i.e., emotional displays and influence tactics) differentiated between the leader types (see Table 6). With respect to emotional styles, the Wilk's lambda for both functions was significant 
(Function $1, \lambda=.60, p<.01$; Function $2, \lambda=.79, p<.01$ ). Overall, the DFA suggests that leadership types can be discriminated based on emotional styles, with function 1 exhibiting negative style and function 2 exhibiting logical/authentic style. Negative emotional display ( $r=.66$.), emotional volatility $(r=.37)$, and negative or unsanctioned tactics $(r=.76)$ were predictors of group classification on the negative style function, and positive emotional display $(r=-.56)$, positive or sanctioned tactics $(r=-.50)$, authenticity $(r=.60)$, and logical reasoning tactics $(r=.50)$ were predictors of group classification on the logical/authentic style function. Classification results for charismatic leaders (F1 $M=-.25, \mathrm{~F} 2 M=-.70)$, ideological leaders (F1 $M=.75, \mathrm{~F} 2 M$ $=.14)$, and pragmatic leaders $(\mathrm{F} 1 M=-.53, \mathrm{~F} 2 M=.53)$ are $63.3 \%, 62.5 \%$, and $64.5 \%$, respectively. These results suggest that charismatics exhibit higher levels of positive displays and use positive or sanctioned tactics, ideologues exhibit higher negative displays, use more negative or unsanctioned tactics, and are more emotionally volatile, and pragmatics avoid strong emotional displays and use more logical reasoning tactics. These findings bolster mean differences between the groups and suggest that CIP leader types rely on a particular emotional style and further supports hypotheses 1-7.

\section{Affective Congruence}

Regression analyses examining the effects of affective congruence showed some interesting patterns (see Table 7). In short, no significant interactive effects were observed. However, the beta weights associated with some of the interaction terms were relatively large and may be stronger in a larger sample. These findings do not support for hypotheses 8, 9, and 10 . 


\section{Discussion}

Previous work in this area maintains that positive valance emotional display variables predict effectiveness outcomes (Gooty, et al., 2010; Illies, et al., 2012), but the framework of the CIP model and subsequent validation efforts hold that there are multiple pathways to leadership success (Hunter, et al., 2011; Mumford, 2006). The observed means and patterns of discrimination in this study provided support for that idea. In general, emotional displays and influence tactics did show patterns of mean differences among the CIP leadership types in ways that are consistent with the CIP theoretical framework and empirical investigations (Hunter et al., 2011; Mumford, 2006; Mumford \& Van Doorn, 2001; Strange \& Mumford, 2005), and findings suggest that CIP leader types may also have distinct emotional styles. Further, all overall measures of leadership outcomes (i.e., communication effectiveness, follower satisfaction, and leadership effectiveness) showed similar levels across CIP leadership type. It was not until delving further into the subscales subsumed in overall outcomes scales that differences surfaced that differentiated the CIP leader types. For instance, mean differences examining specific behaviors associated with leadership effectiveness suggested that pragmatic leaders were better at task-oriented behaviors and charismatic leaders were better at relationship-oriented behaviors. This may suggest that outstanding leaders make up for their weaknesses in one type of behavior by accentuating their strengths in another.

\section{Limitations}

Before turning to the broader theoretical and practical implications of this study, some limitations must be noted. First, the sample size associated with this study 
is somewhat small. This is problematic in that a small sample limits the power or ability to observe effects within and across leader types. This is particularly troublesome given our use of regression analyses for testing the predictive power of our variables of interest with respect to communication effectiveness, follower satisfaction, and leadership effectiveness. As such, it is likely that our sample size is not large enough to examine multiple interactive effects within each regression analysis. Examination of beta weights associated with interactive effects would also support this notion. We strongly urge future research to examine these patterns with a larger sample size within each of the leadership types.

Second, this sample largely consists of Western leaders given the criteria for inclusion regarding leader speeches. While efforts were made to include leaders from multiple nations and there were no observed significant differences within the sample in terms of Western and non-Western leaders, inclusion of more non-Western leaders may potentially alter the results. Similarly, extensive efforts were made to include a diverse sample of leaders regarding gender, age, leadership field, among other variables, but, as noted in the method section, some of these variables (e.g., leadership field) tend to be predominantly classified as one type of leader over another. To account for this, diversity variables were initially included as control variables in all regression models, but none of these variables were significant and were dropped from the final analyses. Overall, these variables tended to have minimal effects. Nonetheless, we urge future research to investigate similar hypotheses with a larger and more inclusive sample size to investigate potential differences in findings are a result of sampling issues. 
Finally, this study used one, generally quintessential, publicly available speech for each leader. These speeches were limited to 15 minutes excerpts as a means of standardization. In some instances, the selected speech and speech length may not fully reflect the leader's range of emotional displays, use of influence tactics, or communication effectiveness. However, based on the dimensions within the CIP model, the framing of the message is of most import (Mumford, 2006). As such, the leader's consistent pattern of message framing is not likely to vary much from speech to speech (cf., Shamir, Arthur, \& House, 1994). Nonetheless, future research should examine multiple, full-length speeches that are equal in length to provide a more detailed and rich picture of the leader in terms of affect, influence, and communication effectiveness.

\section{Implications}

The emotional display variables identified as discriminating the CIP leadership types have been explored in some previous research (e.g., positive and negative) while others have not been previously investigated (e.g., authenticity and emotional volatility). Mean differences show that leader types exhibit pronounced differences in emotional display variables that extend beyond those examined in Hunter, et al. (2011). Our results suggest that emotional stability and perceptions of authenticity are not skills that extend to every outstanding leader, which comes in direct conflict with previous research concerning charismatic and transformational leaders (Conger \& Kanugo, 1987; House, 1977; Shamir, et al, 1993) and more recent research in the area of authenticity (Avolio \& Gardner, 2005) that suggests that simply displaying positive emotions that are in line with a leader's true feelings are related to both follower 
satisfaction and leadership effectiveness. Instead, similar to Trilling and Trilling (1972), the current effort found that leaders who do not heavily rely on emotions to communication or influence others are perceived as more authentic. Additionally, ideological leaders were more likely to be perceived as emotionally volatile. Little research has explored this link previously, but this finding is in line with Keltner (1994) who found that neuroticism predicted displays of anger, contempt, and fear emotions that ideological leaders appear to use to communicate goals to followers and influence others.

Additionally, our results also suggest these leaders use influence tactics that coincide with their broader messages and goals (Mumford, 2006; Yukl \& Tracey, 1992). Our results find that charismatics favor influence tactics that highlight the positive outlook of the future; ideologues rely on influence tactics that draw attention to individuals or events that have contributed to perceived wrongs; and pragmatics use influence tactics that stress logic and utilitarianism. These results generally coincide with previous research within the CIP realm that also found the differing leadership types favor the use of some influence tactics over others and provide further support for the exploration of influence tactics undertaken by Mumford and colleagues (2006). It is worth noting that the limited number of influence tactics investigated in this study were chosen based on their likelihood of predicting meaningful differences between leadership types. Mumford and colleagues (2006) found somewhat differing patterns of favored influence tactics in their investigation, however, the underlying trends were retained in this study. It is plausible that additional political tactics or bases of power not investigated in this study would also contribute to positive, negative, and logical 
influence tactics categories (e.g., using symbols and ritual, control of information, and image building; Zanzi \& O’Neill, 2001). Further, what followers perceive as sanctioned and unsanctioned tactics and how they react to those tactics may differ depending on CIP leader type and leader goals (Griffith, Connelly, \& Thiel, 2011; Thiel, Connelly, \& Griffith, in press). As such, this area is ripe for future inquiry.

Finally, our results also lend support to the notion that the use of emotions coincides with the leader's broader message, culminating in the form of an emotional style. Future-focused, vision-based charismatics rely on positive emotions; pastfocused, values-based ideologues that point to adverse events to support their message use more negative emotions; and present-focused pragmatics tend to use less emotion altogether than either of their counterparts. Our data suggests that use of particular clusters of emotional displays and influence tactics are relevant discriminators between CIP leader types. Specific emotional styles may act in similar ways to other dimensions already integrated into the CIP Model to promote high instances of leadership effectiveness (Mumford, 2006).

This is particularly noteworthy given the overwhelmingly optimistic bias within leadership research that dictates that displaying positive affect as a leader is superior to other emotional displays in terms of beneficial outcomes and consequences (Bono \& Illies, 2006; George \& Bettenhausen, 1990; George, 1995; Luthans, 2002) and displaying or experiencing negative emotions is linked to negative leadership outcomes (Dasborough and Ashkanasy, 2009, Gaddis et al., 2004, McColl-Kennedy and Anderson, 2002). In this regard, it may be fruitful to investigate leadership and organizational outcomes that are heavily influenced by leader emotional displays (e.g., 
organizational commitment). This is especially relevant as leader style and the ways that leaders interaction with followers has been shown to have a wide-reaching impact on organizational culture and other organizational variables tied to employee attitudes, emotions, and performance (Gregory, Harris, Armenakis, \& Shook, 2009; Lok \& Crawford, 1999; Patterson, Warr, \& West, 2004).

\section{Conclusions}

Effective leaders do, indeed, reach similar high performing end states through differential means within various dimensions as suggested in the CIP leadership framework (Hunter, et al., 2011; Mumford, 2006; Mumford \& Van Doorn, 2001; Strange \& Mumford, 2002). In the current effort, our results expand the CIP Model of Leadership by exploring and showing support for the discriminating power of a potentially new dimension containing various emotional display variables. As such, future research should work to provide more evidence of the ability of emotional displays to successfully discriminate between the leadership types. Additionally, our results extend Hunter, et al.'s (2011) initial exploration of emotional displays with a larger, more inclusive sample and more emotional display variables. Given this finding, more research should focus on emotional displays and leadership outcomes from this paradigm to offer more insight into the complex relationship between emotional displays and other variables that may work in conjunction to impact communication effectiveness, follower satisfaction, and leadership effectiveness. 


\section{References}

Ahearn, K. K., Ferris, G. R., Hochwarter, W. A., Douglas, C., \& Ammeter, A. P. (2004). Leader political skill and team performance. Journal of Management, 30(3), 309-327.

Avolio, B. J., \& Gardner, W. L. (2005). Authentic leadership development: Getting to the root of positive forms of leadership. The leadership quarterly, 16(3), 315338.

Avolio, B. J., Walumbwa, F. O., \& Weber, T. J. (2009). Leadership: Current theories, research, and future directions. Annual review of psychology, 60, 421-449.

Bachorowski, J. A. (1999). Vocal expression and perception of emotion. Current directions in psychological science, 8(2), 53-57.

Bass, B. (1985). Leadership and performance beyond expectations. New York: Free Press.

Bass, B. (1988). The inspirational processes of leadership. Journal of Management Development, 7(5), 21-31.

Bernardin, H. J., \& Buckley, M. R. (1981). Strategies in rater training. Academy of Management Review, 205-212.

Bono, J. E., \& Ilies, R. (2006). Charisma, positive emotions and mood contagion. The Leadership Quarterly, 17(4), 317-334.

Bono, J. E., \& Ilies, R. (2006). Charisma, positive emotions and mood contagion. The Leadership Quarterly, 17(4), 317-334.

Bucy, E. P. (2000). Emotional and evaluative consequences of inappropriate leader displays. Communication Research, 27(2), 194-226. 
Burns, J. M. (1978). Leadership. New York: Harper \& Row.

Cacioppo, J. T., \& Gardner, W. L. (1999). Emotion. Annual review of psychology, $50(1), 191-214$

Calantone, R. J., \& Schatzel, K. E. (2000). Strategic foretelling: Communicationbased antecedents of a firm's propensity to preannounce. The Journal of Marketing, 17-30.

Carson, M. A., Shanock, L. R., Heggestad, E. D., Andrew, A. M., Pugh, S. D., \& Walter, M. (2012). The relationship between dysfunctional interpersonal tendencies, derailment potential behavior, and turnover. Journal of Business and Psychology, 27(3), 291-304.

Chaiken , S. (1978). The use of source and message cues in persuasion: An information processing analysis. Unpublished doctoral dissertation, University of Massachusetts-

Amherst.

Chaiken, S., \& Liberman, A., \& Eagly, A. H. (1989). Heuristic and systematic information processing within and beyond the persuasion context. Unintended thought. 'Limits of awareness, intention, and control (pp. 2I2-252). New York:

\section{Guilford.}

Cogliser, C. C., Schriesheim, C. A., Scandura, T. A., \& Gardner, W. L. (2009). Balance in leader and follower perceptions of leader-member exchange: Relationships with performance and work attitudes. The Leadership Quarterly, $20(3), 452-465$ 
Conger, J. A., \& Kanungo, R. N. (1987). Toward a behavioral theory of charismatic leadership in organizational settings. Academy of management review, 637-647.

Conger, J. A., Kanungo, R. N., \& Menon, S. T. (2000). Charismatic leadership and follower effects. Journal of organizational Behavior, 21(7), 747-767.

Connelly, S., Gaddis, B., \& Helton-Fauth, W. (2002). A closer look at the role of emotions in transformational and charismatic leadership. Transformational and charismatic leadership: The road ahead, 2, 255-283.

Connelly, S., \& Ruark, G. (2010). Leadership style and activating potential moderators of the relationships among leader emotional displays and outcomes. The Leadership Quarterly, 21(5), 745-764.

Damen, F., Van Knippenberg, B., \& Van Knippenberg, D. (2008). Affective Match in Leadership: Leader Emotional Displays, Follower Positive Affect, and Follower Performance1. Journal of Applied Social Psychology, 38(4), 868-902.

Dansereau, F., Graen, G., \& Haga, W. J. (1975). A vertical dyad linkage approach to leadership within formal organizations: A longitudinal investigation of the role making process. Organizational behavior and human performance, 13(1), 4678.

Dillard, J. P., \& Anderson, J. W. (2004). The role of fear in persuasion. Psychology \& Marketing, 21(11), 909-926.

Eberly, M. B., \& Fong, C. T. (2010). Follower reactions to leader affect: How emotion valence and sincerity shape leader effectiveness. Unpublished dissertation. Foster School of Business, University of Washington. 
Erez, A., Misangyi, V. F., Johnson, D. E., LePine, M. A., \& Halverson, K. C. (2008). Stirring the hearts of followers: Charismatic leadership as the transferal of affect. Journal of Applied Psychology, 93(3), 602-616.

Ferris, G. R., Zinko, R., Brouer, R. L., Buckley, M. R., \& Harvey, M. G. (2007). Strategic bullying as a supplementary, balanced perspective on destructive leadership. The Leadership Quarterly, 18(3), 195-206.

Fiedler, F. E. (1971). Validation and extension of the contingency model of leadership effectiveness: A review of empirical findings. Psychological Bulletin, 76(2), 128.

Fisher, C. D., \& Ashkanasy, N. M. (2000). The emerging role of emotions in work life: An introduction. Journal of Organizational Behavior, 21(2), 123-129.

Fleishman, E. A., Mumford, M. D., Zaccaro, S. J., Levin, K. Y., Korotkin, A. L., \& Hein, M. B. (1992). Taxonomic efforts in the description of leader behavior: A synthesis and functional interpretation. The Leadership Quarterly, 2(4), 245287.

Fonagy, I., \& Magdics, K. (1963). Emotional patterns in intonation and music. Zeitschrift für Phonetik, 16(1-3), 293-326.

Gaddis, B., Connelly, S., \& Mumford, M. D. (2004). Failure feedback as an affective event: Influences of leader affect on subordinate attitudes and performance. The Leadership Quarterly, 15(5), 663-686.

Gardner, W. L., Avolio, B. J., Luthans, F., May, D. R., \& Walumbwa, F. (2005). “Can you see the real me?" A self-based model of authentic leader and follower development. The Leadership Quarterly, 16(3), 343-372. 
Graen, G. B., \& Uhl-Bien, M. (1995). Relationship-based approach to leadership: Development of leader-member exchange (LMX) theory of leadership over 25 years: Applying a multi-level multi-domain perspective. The Leadership Quarterly, 6(2), 219-247.

Gregory, B. T., Harris, S. G., Armenakis, A. A., \& Shook, C. L. (2009). Organizational culture and effectiveness: A study of values, attitudes, and organizational outcomes. Journal of Business Research, 62(7), 673-679.

Groves, K. S. (2006). Leader emotional expressivity, visionary leadership, and organizational change. Leadership \& Organization Development Journal, 27(7), 566-583.

Hareli, S., \& Rafaeli, A. (2008). Emotion cycles: On the social influence of emotion in organizations. Research in organizational behavior, 28, 35-59.

Harvey, P., Stoner, J., Hochwarter, W., \& Kacmar, C. (2007). Coping with abusive supervision: The neutralizing effects of ingratiation and positive affect on negative employee outcomes. The Leadership Quarterly, 18(3), 264-280.

Hogan, R., \& Kaiser, R. B. (2005). What we know about leadership. Review of general psychology, 9(2), 169.

Hogan, R., Curphy, G. J., \& Hogan, J. (1994). What we know about leadership: Effectiveness and personality. American Psychologist, 49, 493-493.

Holladay, S. J., \& Coombs, W. T. (1994). Speaking of visions and visions being spoken an exploration of the effects of content and delivery on perceptions of leader charisma. Management Communication Quarterly, 8(2), 165-189. 
House, R. J. (1977). A 1976 theory of charismatic leadership effectiveness. Leadership: The cutting edge. Feffer and Simons, Carbondale.

Howell, J. P., \& Costley, D. L. (2001). Understanding behaviors for effective leadership. Prentice Hall.

Hunter, S. T., Cushenbery, L., Thoroughgood, C., Johnson, J. E., \& Ligon, G. S. (2011). First and ten leadership: A historiometric investigation of the CIP leadership model. The Leadership Quarterly, 22(1), 70-91.

Ilies, R., Curşeu, P. L., Dimotakis, N., \& Spitzmuller, M. (2012). Leaders' emotional expressiveness and their behavioural and relational authenticity: Effects on followers. European Journal of Work and Organizational Psychology, (aheadof-print), 1-19.

Jablin, F. M. (1979). Superior-subordinate communication: The state of the art. Psychological bulletin, 86(6), 1201.

Judge, T. A., \& Bono, J. E. (2000). Five-factor model of personality and transformational leadership. Journal of applied psychology, 85(5), 751-765.

Judge, T. A., Bono, J. E., Ilies, R., \& Gerhardt, M. W. (2002). Personality and leadership: a qualitative and quantitative review. Journal of applied psychology, 87(4), 765.

Kaiser, R. B., \& Hogan, R. (2007). The dark side of discretion: Leader personality and organizational decline. Being there even when you are not: Leading through strategy, systems and structures. Monographs in leadership and management, 4, 177-197. 
Keltner, D. (1996). Facial expressions of emotion and personality. Handbook of emotion, adult development, and aging, 385-401.

Keltner, D., \& Haidt, J. (1999). Social functions of emotions at four levels of analysis. Cognition \& Emotion, 13(5), 505-521.

Kipnis, D., \& Schmidt, S. M. (1988). Upward-influence styles: Relationship with performance evaluations, salary, and stress. Administrative Science Quarterly, $528-542$.

Knapp, M. L., \& Hall, J. A. (2009). Nonverbal communication in human interaction. Wadsworth Publishing Company.

Knutson, B. (1996). Facial expressions of emotion influence interpersonal trait inferences. Journal of Nonverbal Behavior, 20(3), 165-182.

Lemann, N. (2000). The big test: The secret history of the American meritocracy. Farrar, Straus and Giroux.

Liu, Y., \& Perrewe, P. L. (2006). Are they for real? The interpersonal and intrapersonal outcomes of perceived authenticity. International Journal of Work Organisation and Emotion, 1(3), 204-214.

Lok, P., \& Crawford, J. (1999). The relationship between commitment and organizational culture, subculture, leadership style and job satisfaction in organizational change and development. Leadership \& Organization Development Journal, 20(7), 365-374.

McColl-Kennedy, J. R., \& Anderson, R. D. (2002). Impact of leadership style and emotions on subordinate performance. The Leadership Quarterly, 13(5), 545559. 
Michie, S., \& Gooty, J. (2005). Values, emotions, and authenticity: Will the real leader please stand up?. The Leadership Quarterly, 16(3), 441-457.

Mumford, M. D. (2006). Pathways to outstanding leadership: A comparative analysis of charismatic, ideological, and pragmatic leaders. Psychology Press.

Mumford, M. D., Antes, A. L., Caughron, J. J., \& Friedrich, T. L. (2008). Charismatic, ideological, and pragmatic leadership: Multi-level influences on emergence and performance. The Leadership Quarterly, 19(2), 144-160.

Mumford, M. D., Strange, J. M., Gaddis, B., Licuanan, B., \& Scott, G. (2006). Performance: Who Masters the Art of Influence? Charismatic, Ideological, or Pragmatic Leaders?. Pathways to outstanding leadership: A comparative analysis of charismatic, ideological, and pragmatic leadership, 81-107.

Mumford, M. D., \& Van Doorn, J. R. (2001). The leadership of pragmatism: Reconsidering Franklin in the age of charisma. The Leadership Quarterly, 12(3), 279-309.

Mumford, M. D., Espejo, J., Hunter, S. T., Bedell-Avers, K. E., Eubanks, D. L., \& Connelly, S. (2007). The sources of leader violence: A comparison of ideological and non-ideological leaders. The Leadership Quarterly, 18(3), 217235.

Newcombe, M. J., \& Ashkanasy, N. M. (2002). The role of affect and affective congruence in perceptions of leaders: An experimental study. The Leadership Quarterly, 13(5), 601-614. 
Newcombe, M. J., \& Ashkanasy, N. M. (2002). The role of affect and affective congruence in perceptions of leaders: An experimental study. The Leadership Quarterly, 13(5), 601-614.

Novicevic, M. M., Harvey, M. G., Ronald, M., \& Brown-Radford, J. A. (2006). Authentic leadership: A historical perspective. Journal of Leadership \& Organizational Studies, 13(1), 64-76.

Pakosz, M. (1983). Attitudinal judgments in intonation: Some evidence for a theory. Journal of Psycholinguistic Research, 12(3), 311-326.

Patterson, M., Warr, P., \& West, M. (2004). Organizational climate and company productivity: The role of employee affect and employee level. Journal of Occupational and Organizational Psychology, 77(2), 193-216.

Rejai, M. (1995). Political Ideologies: A Comparative Aproach. ME Sharpe Inc.

Riggio, R. E., \& Lee, J. (2007). Emotional and interpersonal competencies and leader development. Human Resource Management Review, 17(4), 418-426.

Riggio, R. E., Riggio, H. R., Salinas, C., \& Cole, E. J. (2003). The role of social and emotional communication skills in leader emergence and effectiveness. Group Dynamics: Theory, Research, and Practice, 7(2), 83.

Rogers, R. W. (1975). A Protection Motivation Theory of Fear Appeals and Attitude Change1. The Journal of Psychology, 91(1), 93-114.

Schaubroeck, J., Lam, S. S., \& Cha, S. E. (2007). Embracing transformational leadership: Team values and the impact of leader behavior on team performance. Journal of Applied Psychology, 92(4), 1020-1030. 
Schwarz, N., \& Clore, G. L. (1983). Mood, misattribution, and judgments of wellbeing: Informative and directive functions of affective states. Journal of personality and social psychology, 45(3), 513.

Shamir, B., \& Howell, J. M. (1999). Organizational and contextual influences on the emergence and effectiveness of charismatic leadership. The Leadership Quarterly, 10(2), 257-283.

Shamir, B., Arthur, M. B., \& House, R. J. (1994). The rhetoric of charismatic leadership: A theoretical extension, a case study, and implications for research. The Leadership Quarterly, 5(1), 25-42.

Shamir, B., House, R. J., \& Arthur, M. B. (1993). The motivational effects of charismatic leadership: A self-concept based theory. Organization science, $4(4), 577-594$.

Silvester, J. (2008). 4 The Good, the Bad and the Ugly: Politics and Politicians at Work. International review of industrial and organizational psychology, 23, 107.

Strange, J. M., \& Mumford, M. D. (2002). The origins of vision: Charismatic versus ideological leadership. The Leadership Quarterly, 13(4), 343-377.

Strange, J. M., \& Mumford, M. D. (2005). The origins of vision: Effects of reflection, models, and analysis. The Leadership Quarterly, 16(1), 121-148.

Tiedens, L. Z. (2001). Anger and advancement versus sadness and subjugation: The effect of negative emotion expressions on social status conferral. Journal of personality and social psychology, 80(1), 86-94.

Trilling, L., \& Trilling, L. (1972). Sincerity and authenticity. Harvard University Press. 
Van Kleef, G. A., De Dreu, C. K., \& Manstead, A. S. (2004). The interpersonal effects of anger and happiness in negotiations. Journal of personality and social psychology, 86(1), 57-76.

Van Knippenberg, D., Van Knippenberg, B., De Cremer, D., \& Hogg, M. A. (2004). Leadership, self, and identity: A review and research agenda. The Leadership Quarterly, 15(6), 825-856.

Waples, E. P., \& Connelly, S. (2008). Leader emotions and vision implementation. Affect and Emotions: New Directions in Management Theory and Research. Charlotte, NC: Information Age Publishing, 67-96.

Watson, D. (2000) Mood and temperament. NY: Guildford Press.

Watson, D., \& Clark, L. A. (1984). Negative affectivity: the disposition to experience aversive emotional states. Psychological bulletin, 96(3), 465.

Yorges, S. L., Weiss, H. M., \& Strickland, O. J. (1999). The effect of leader outcomes on influence, attributions, and perceptions of charisma. Journal of Applied Psychology, 84(3), 428.

Yukl, G., \& Tracey, J. B. (2003). Consequences of influence tactics used with subordinates, peers, and the boss. Organizational Influence Processes (Porter, LW, et al. Eds.), New York, ME Sharpe, 96-116.

Yukl, G., Kim, H., \& Chavez, C. (1999). Task importance, feasibility, and agent influence behavior as determinants of target commitment. Journal of Applied psychology, 84(1), 137.

Zanzi, A., \& O'Neill, R. M. (2001). Sanctioned versus non-sanctioned political tactics. Journal of Managerial Issues, 245-262. 
Table 1

Leadership Classification Results

\begin{tabular}{|c|c|c|}
\hline Charismatic Leaders & Ideological Leaders & Pragmatic Leaders \\
\hline 1. Abdullah II of Jordan & 1. $\quad$ Bella Abzug & 1. Kofi Annan \\
\hline 2. Madeleine Albright & 2. Idi Amin & 2. Benazir Bhutto \\
\hline 3. Tony Blair & 3. Jim Bakker & 3. Michael Bloomberg \\
\hline 4. Nicolae Ceau $\square$ escu & 4. Osama bin Laden & 4. Warren Buffett \\
\hline 5. Bill Clinton & 5. Pat Buchanan & 5. George H. W. Bush \\
\hline 6. Geraldine Ferraro & 6. Fidel Castro & 6. Dick Cheney \\
\hline 7. Jane Goodall & 7. Michael Eisner & 7. Wesley Clark \\
\hline 8. Al Gore & 8. Larry Ellison & 8. Hilary Clinton \\
\hline 9. Dalai Lama, Tenzin & 9. Jerry Falwell & 9. Walter Cronkite \\
\hline Gyatso & 10. Louis Farrakhan & 10. Kim Dae-Jung \\
\hline 10. Adolf Hitler & 11. Diane Feinstein & 11. Jamie Dimon \\
\hline 11. Herbert Hoover & 12. Milton Friedman & 12. Dwight D. Eisenhower \\
\hline 12. David Hume & 13. Billy Graham & 13. Queen Elizabeth II of \\
\hline 13. Lee Iacocca & 14. Che Guevara & England \\
\hline 14. Barbara Jordan & 15. Kay Bailey Hutchison & 14. Bill Gates \\
\hline 15. Michael Jordan & 16. Jesse Jackson & 15. Rudy Giuliani \\
\hline 16. Juan Carlos I of Spain & 17. Steve Jobs & 16. Berry Gordy, Jr. \\
\hline 17. Edward (Ted) Kennedy & 18. Ayatollah Khomeini & 17. Katharine Graham \\
\hline 18. John F. Kennedy & 19. Lyndon LaRouche & 18. Lyndon Baines \\
\hline 19. Robert F. Kennedy & 20. Huey Long & Johnson \\
\hline 20. Martin Luther King, Jr. & 21. Joseph McCarthy & 19. Henry Kissinger \\
\hline 21. Douglas MacArthur & 22. Michael Moore & 20. Michael Milken \\
\hline 22. Malcolm X & 23. Hosni Mubarak & 21. Rupert Murdoch \\
\hline 23. Nelson Mandela & 24. Sarah Palin & 22. Ralph Nader \\
\hline 24. Mother Teresa & 25. Ronald Reagan & 23. Benjamin Netanyahu \\
\hline 25. Benito Mussolini & 26. Oral Roberts & 24. Richard M. Nixon \\
\hline 26. Ann Richards & 27. George Lincoln & 25. Larry Page \\
\hline 27. Franklin D. Roosevelt & Rockwell & 26. Bill Parcells \\
\hline 28. Gloria Steinem & 28. Joseph Stalin & 27. Ross Perot \\
\hline 29. Aung San Suu Kyi & 29. Margaret Thatcher & 28. Colin Powell \\
\hline 30. Ted Turner & 30. Donald Trump & 29. Dan Rather \\
\hline 31. Jack Welch & & 30. George Soros \\
\hline 32. Oprah Winfrey & & 31. Harry S. Truman \\
\hline
\end{tabular}


Table 2

Means and Standard Deviations of Study Covariates

\begin{tabular}{lcccccc}
\cline { 2 - 7 } & \multicolumn{2}{c}{$\begin{array}{c}\text { Charismatic } \\
\text { Leaders }\end{array}$} & \multicolumn{2}{c}{$\begin{array}{c}\text { Ideological } \\
\text { Leaders }\end{array}$} & \multicolumn{2}{c}{$\begin{array}{c}\text { Pragmatic } \\
\text { Leaders }\end{array}$} \\
\cline { 2 - 7 } & $M$ & $S D$ & $M$ & $S D$ & $M$ & $S D$ \\
\hline Biography Covariates & & & & & & \\
Level of Detail & 3.34 & 0.44 & 3.51 & 0.48 & 3.33 & 0.41 \\
Biographer Evaluation & $\mathbf{1 . 8 7}$ & $\mathbf{0 . 3 1}$ & $\mathbf{1 . 7 6}$ & $\mathbf{0 . 3 3}$ & $\mathbf{1 . 9 4}$ & $\mathbf{0 . 1 9}$ \\
Age & 35.20 & 9.70 & 38.56 & 14.58 & 39.32 & 13.86 \\
Gender & 1.30 & 0.46 & 1.19 & 0.40 & 1.13 & 0.24 \\
Western/non-Western & 1.20 & 0.41 & 1.23 & 0.43 & 1.20 & 0.40 \\
Power Orientation & $\mathbf{1 . 1 3}$ & $\mathbf{0 . 3 5}$ & $\mathbf{1 . 7 5}$ & $\mathbf{0 . 4 4}$ & $\mathbf{1 . 4 2}$ & $\mathbf{0 . 5 0}$ \\
Frequency of Communication & $\mathbf{4 . 0 0}$ & $\mathbf{0 . 9 5}$ & $\mathbf{3 . 9 7}$ & $\mathbf{0 . 9 0}$ & $\mathbf{3 . 4 5}$ & $\mathbf{1 . 0 3}$ \\
Frequency of Appearances & 3.77 & 0.90 & 3.44 & 0.88 & 3.32 & 1.25 \\
Speech Covariates & & & & & & \\
Audience Size & 3.91 & 1.65 & 4.06 & 2.03 & 3.76 & 1.84 \\
Video Quality & $\mathbf{3 . 4 3}$ & $\mathbf{1 . 0 0}$ & $\mathbf{3 . 0 4}$ & $\mathbf{1 . 0 6}$ & $\mathbf{3 . 8 0}$ & $\mathbf{0 . 9 4}$ \\
Total Length of Speech (minutes) & 20.70 & 11.85 & 28.81 & 11.52 & 27.21 & 9.43 \\
Expression Visibility & 4.03 & 0.65 & 3.86 & 0.86 & 4.11 & 0.74 \\
Focus on Audience & 2.22 & 0.86 & 1.97 & 0.86 & 1.86 & 0.85 \\
\hline Note. Tota
\end{tabular}

Note. Total sample size is 93, with 32 charismatic leaders, 30 ideological leaders, and 31 pragmatic leaders. Biographer evaluation: $1=$ negative, $2=$ positive, Gender: $1=$ male, $2=$ female, Western/non-Western: 1= Western, 2= non-Western. Bolded values indicate significant difference between CIP leader types at $p<.05$. 
Table 3

Frequencies of Leader Field and Speech Types

\begin{tabular}{|c|c|c|c|}
\hline & $\begin{array}{l}\text { Charismatic } \\
\text { Leaders }\end{array}$ & $\begin{array}{c}\text { Ideological } \\
\text { Leaders } \\
\end{array}$ & $\begin{array}{c}\text { Pragmatic } \\
\text { Leaders }\end{array}$ \\
\hline & $N$ & $N$ & $N$ \\
\hline \multicolumn{4}{|l|}{ Leader Field } \\
\hline Business and Industry & 5 & 5 & 9 \\
\hline Government and Politics & 15 & 14 & 15 \\
\hline Social Movements & 4 & 3 & 0 \\
\hline Religious Institutions & 3 & 5 & 0 \\
\hline Military & 1 & 4 & 3 \\
\hline News and Media & 0 & 0 & 2 \\
\hline Education & 0 & 1 & 1 \\
\hline Science and Research & 1 & 0 & 0 \\
\hline Athletics and Coaching & 1 & 0 & 1 \\
\hline \multicolumn{4}{|l|}{ Speech Type } \\
\hline Country-Wide Addresses & 2 & 8 & 4 \\
\hline Campaign Speech & 9 & 8 & 2 \\
\hline Commencement Address & 2 & 0 & 0 \\
\hline Award or Acceptance Speech & 1 & 0 & 2 \\
\hline $\begin{array}{l}\text { Stockholder and Company } \\
\text { Address }\end{array}$ & 2 & 1 & 1 \\
\hline Inaugural Address & 3 & 0 & 5 \\
\hline Keynote and Invited Lectures & 7 & 7 & 17 \\
\hline Social Events and Rallies & 2 & 3 & 0 \\
\hline Press Conference & 1 & 2 & 0 \\
\hline Sermon & 1 & 3 & 0 \\
\hline
\end{tabular}


Table 4

Means, Standard Deviations, and Inter-rater Agreement of Study Variables

\begin{tabular}{lcccccc} 
& \multicolumn{2}{c}{$\begin{array}{c}\text { Charismatic } \\
\text { Leaders }\end{array}$} & \multicolumn{2}{c}{$\begin{array}{c}\text { Ideological } \\
\text { Leaders }\end{array}$} & \multicolumn{2}{c}{$\begin{array}{c}\text { Pragmatic } \\
\text { Leaders }\end{array}$} \\
\cline { 2 - 7 } & $M$ & $S D$ & $M$ & $S D$ & $M$ & $S D$ \\
\hline Emotional Displays & & & & & & \\
$\quad$ Positive Emotional Displays (.90) & 2.64 & 0.87 & 2.07 & 0.86 & 2.10 & 0.82 \\
$\quad$ Negative Emotional Displays (.93) & 1.59 & 0.55 & 2.22 & 0.92 & 1.57 & 0.63 \\
Authenticity (.83) & 3.93 & 0.80 & 4.17 & 0.42 & 4.35 & 0.35 \\
Emotional Volatility (.73) & 2.53 & 1.00 & 3.06 & 1.05 & 2.67 & 0.99 \\
\hline Influence Tactics & & & & & & \\
Logical Reasoning Tactics (.69) & 1.88 & 0.98 & 2.14 & 0.91 & 2.48 & 0.96 \\
Positive Influence Tactics (.70) & 2.70 & 0.85 & 2.47 & 0.58 & 2.26 & 0.61 \\
Negative Influence Tactics (.85) & 1.59 & 0.55 & 2.22 & 0.92 & 1.57 & 0.63 \\
\hline Outcome Variables & & & & & & \\
$\quad$ Comm Effectiveness (.76) & 3.67 & 0.41 & 3.66 & 0.54 & 3.63 & 0.57 \\
Follower Satisfaction (.93) & 3.94 & 0.58 & 3.70 & 0.67 & 3.73 & 0.60 \\
Leader Effectiveness (.86) & 4.05 & 0.47 & 3.82 & 0.50 & 3.93 & 0.50 \\
$\quad$ Task (.82) & 3.99 & 0.42 & 3.74 & 0.58 & 4.13 & 0.51 \\
$\quad$ Relationship (.83) & 3.99 & 0.55 & 3.78 & 0.45 & 3.78 & 0.61 \\
\hline
\end{tabular}


Table 5

Correlations and Reliabilities Among Study Variables

\begin{tabular}{|c|c|c|c|c|c|c|c|c|c|c|c|c|c|c|}
\hline & $\mathrm{M}$ & SD & 1 & 2 & 3 & 4 & 5 & 6 & 7 & 8 & 9 & 10 & 11 & 12 \\
\hline 1. Positive Emotional Display & 2.26 & .88 & $(0.89)$ & & & & & & & & & & & \\
\hline 2. Negative Emotional Display & 2.06 & .91 & 0.10 & $(0.90)$ & & & & & & & & & & \\
\hline 3. Authenticity & 4.15 & .58 & -0.14 & -0.03 & - & & & & & & & & & \\
\hline 4. Emotional Volatility & 2.76 & 1.03 & -0.05 & -0.10 & 0.02 & - & & & & & & & & \\
\hline 6. Positive Tactics & 2.75 & .70 & 0.41 & 0.19 & 0.00 & 0.05 & $(0.43)$ & & & & & & & \\
\hline 6. Negative Tactics & 1.80 & .77 & -0.14 & 0.62 & 0.04 & 0.07 & -0.01 & $(0.50)$ & & & & & & \\
\hline 7. Logical Tactics & 1.63 & .51 & -0.29 & 0.02 & 0.00 & 0.02 & -0.27 & 0.08 & - & & & & & \\
\hline 8. Comm. Effectiveness & 3.65 & .50 & -0.05 & -0.14 & -0.02 & 0.02 & 0.10 & -0.17 & 0.07 & $(0.75)$ & & & & \\
\hline 9. Follower Satisfaction & 3.79 & .62 & 0.24 & 0.05 & -0.08 & 0.03 & 0.13 & -0.13 & -0.08 & 0.15 & $(0.92)$ & & & \\
\hline 10. Leader Effectiveness & 3.93 & .50 & 0.17 & -0.07 & -0.07 & -0.02 & 0.01 & -0.25 & 0.07 & 0.07 & 0.62 & $(0.74)$ & & \\
\hline 11. Task & 3.95 & .53 & 0.06 & -0.16 & 0.04 & -0.01 & -0.10 & -0.28 & 0.16 & 0.03 & 0.40 & 0.84 & $(0.69)$ & \\
\hline 12. Relationship & 3.85 & .55 & 0.23 & 0.00 & -0.10 & -0.01 & 0.08 & -0.17 & -0.09 & 0.06 & 0.72 & 0.88 & 0.55 & $(0.57)$ \\
\hline
\end{tabular}

Note. Total sample size is 93, with 32 charismatic leaders, 30 ideological leaders, and 31 pragmatic leaders. Reliability is presented in parentheses next to each variable as applicable. For CIP Leader type, $1=$ charismatic, $2=$ ideological, and $3=$ pragmatic. Italics indicates significance at the .10 level. Bold indicates significance at or below the .05 level 
Table 6

\begin{tabular}{lcccc} 
Discriminant Function Analysis Structure & Matrix and Classification Results \\
\hline & Classification & Centroids & Centroids & \\
& Accuracy & Function 1 & Function 2 & \\
\hline Charismatic Leaders & $63.3 \%$ & -0.25 & -0.70 & \\
Ideological Leaders & $62.5 \%$ & 0.75 & 0.14 & \\
Pragmatic Leaders & $64.5 \%$ & -0.53 & 0.53 & \\
\hline & Canonical & Canonical & Structure & Structure \\
& Coefficients & Coefficients & Matrix & Matrix \\
Predictors & Function 1 & Function 2 & Function 1 & Function 2 \\
\hline Positive Emotional Display & -0.33 & -0.26 & -0.20 & $\mathbf{- 0 . 5 6}$ \\
Negative Emotional Display & 0.53 & -0.10 & $\mathbf{0 . 6 6}$ & -0.14 \\
Authenticity & -0.15 & 0.65 & -0.07 & $\mathbf{0 . 6 1}$ \\
Emotional Volatility & 0.47 & 0.20 & $\mathbf{0 . 3 7}$ & 0.19 \\
Positive Tactics & 0.05 & -0.37 & 0.09 & $\mathbf{- 0 . 5 0}$ \\
Negative Tactics & 0.47 & 0.10 & $\mathbf{0 . 7 6}$ & 0.14 \\
Logical Tactics & -0.31 & 0.41 & -0.14 & $\mathbf{0 . 5 0}$ \\
\hline
\end{tabular}

Note: $\mathrm{N}=93$. Both functions are significant at $p<.01$. Bold indicates largest absolute correlation between each variable within discriminant functions. 
Table 7

Regression Analyses for Communication Effectiveness, Follower Satisfaction, and Leader Effectiveness on Emotional Displays and Influence Tactics

\begin{tabular}{lccccc}
\hline & $\begin{array}{c}\text { Communication } \\
\text { Effectiveness }\end{array}$ & $\begin{array}{c}\text { Follower } \\
\text { Satisfaction }\end{array}$ & $\begin{array}{c}\text { Leader } \\
\text { Effectiveness }\end{array}$ & $\begin{array}{c}\text { Task-Oriented } \\
\text { Effectiveness }\end{array}$ & $\begin{array}{c}\text { Relationship-Oriented } \\
\text { Effectiveness }\end{array}$ \\
\hline $\begin{array}{l}\text { Covariates } \\
\text { Biographer Evaluation }\end{array}$ & $\mathbf{0 . 2 2}$ & $\mathbf{0 . 3 8}$ & $\mathbf{0 . 4 9}$ & $\mathbf{0 . 3 7}$ & $\mathbf{0 . 4 4}$ \\
\hline$R^{2}$ & $\mathbf{0 . 0 5}$ & $\mathbf{0 . 1 4}$ & $\mathbf{0 . 2 4}$ & $\mathbf{0 . 1 9}$ & $\mathbf{0 . 1 9}$ \\
\hline
\end{tabular}

\section{Emotional Displays and Influence Tactics}

\begin{tabular}{lrrrrr} 
Positive Emotional Display & -0.14 & 0.13 & 0.11 & 0.06 & 0.12 \\
Negative Emotional Display & -0.06 & 0.23 & 0.18 & 0.09 & 0.19 \\
Authenticity & -0.03 & -0.03 & -0.01 & 0.09 & -0.04 \\
Emotional Volatility & 0.01 & 0.07 & 0.03 & 0.03 & 0.03 \\
Positive Tactics & 0.18 & 0.01 & -0.06 & -0.12 & -0.03 \\
Negative Tactics & -0.07 & -0.07 & -0.14 & $\mathbf{- 0 . 2 7}$ & -0.05 \\
Logical Tactics & 0.05 & -0.10 & 0.05 & 0.13 & -0.11 \\
\hline$R^{2}$ & 0.09 & $\mathbf{0 . 2 2}$ & $\mathbf{0 . 2 7}$ & $\mathbf{0 . 2 3}$ & $\mathbf{0 . 2 5}$ \\
\hline
\end{tabular}

\section{Emotional Displays X Influence Tactics Interaction Terms}

\begin{tabular}{lccccc} 
Positive Tactics*Positive Emotion & 0.54 & -0.31 & 0.29 & 0.12 & 0.39 \\
Positive Tactics*Negative Emotion & 0.38 & -0.39 & -0.24 & 0.26 & -0.45 \\
Negative Tactics*Negative Emotion & -1.03 & 0.18 & 0.13 & 0.73 & -0.09 \\
Negative Tactics*Positive Emotion & -0.62 & 0.09 & 0.41 & 0.58 & 0.25 \\
\hline$R^{2}$ & 0.16 & $\mathbf{0 . 2 4}$ & $\mathbf{0 . 2 9}$ & $\mathbf{0 . 2 7}$ & $\mathbf{0 . 2 7}$ \\
\hline Note: Standardized regression weights presented. Italics indicates significance at the .10 level. Bold indicates significance at the .05 level.
\end{tabular}

Note: Standardized regression weights presented. Italics indicates significance at the .10 level. Bold indicates significance at the .05 level. 